\title{
Bioactivity Investigations with Calcia Magnesia Based
}

\section{Composites}

\author{
Emad Mohamed Mohamed Ewais ${ }^{1 *}$, Amira Moustafa $^{1}$, Karoline Pardun $^{2}$ and Kurosch Rezwan ${ }^{2}$ \\ 1. Refractory \& Ceramic Materials Division, Advanced Materials Department, Central Metallurgical R\&D Institute, Cairo 11421, \\ Egypt
}

2. Advanced Ceramics, University of Bremen, Bremen 28359, Germany

\begin{abstract}
The bioactivity and physico-mechanical properties of calcia magnesia based composites developed in this study were investigated. Different composite mixtures containing calcia-magnesia have been processed with the addition of alumina, silica or zircon. These system powders were formed and fired at two different temperatures. The produced composites were characterized by means of X-ray diffraction, SEM (scanning electron microscope) equipped with EDS (energy dispersive X-ray spectrometry), density and apparent porosity measurements, mechanical testing and in-vitro evaluation in a SBF (simulated body fluid) solution. The compositions termed "I", "II" and "III" gave clear tendency towards the formation-ability of HA (hydroxyapatite). Composite " 1 " gave cubic and spindle HA crystallite, while composites "II" and "III" fired at 1,300 and 1,400 ${ }^{\circ} \mathrm{C}$ formed typically "cauliflower" morphology and their evaluated physico-mechanical properties are similar to the properties of human cortical bone. Thus, composites "II" and "III" might be a promising bone implant materials. Beside the bioactivitiy of composite "I", it also contains highly CA (cementing phase) and MA (bioinert) phases, therefore, it might be nominated as a promising bioceramic material especially for different purposes such as scaffold, bone replacement, bone repair and coating.
\end{abstract}

Key words: Calcia-magnesia, zircon, alumina, SBF, bending strength.

\section{Introduction}

Bioceramics are engineered materials that find applications in the field of medicine [1]. This class of materials, particularly the bioactive one, has become one of the major fields in biomaterials over the last three decades due to its attractive feature for bone repair such as direct bone-bonding in the body. The essential condition of artificial materials to show bioactivity is the formation of bone-like apatite on their surfaces in body environment. The brittleness, low fracture toughness and low impact resistance of the bioceramics have limited their applications. Nevertheless, at the end of the sixties, a strong interest in the use of ceramics for biomedical engineering applications was developed. Since then, further improvements in ceramic properties have been made

Corresponding author: Emad Mohamed Mohamed Ewais, Professor, Dr., research fields: refractories and ceramics. E-mail: dr_ewais@hotmail.com. and opened the wide span of their biomedical applications [2,3].

When bioactive materials are implanted into the human body, they interact with the surrounding bones or other tissue to some extent. An ion-exchange reaction between the bioactive implant and surrounding body fluids results in the formation of a biologically active carbonate-containing hydroxyapatite layer on the implant that is chemically and crystallographically equivalent to the mineral phase in the bone, which promotes the bonding between the natural tissues and the material. Like other bioactive materials, bioactive ceramics can directly bond to the living bone tissue. Sintered HA (hydroxyapatite) has been recorded a remarkable success as implant materials in the clinical use due to its bioactivity and osteoconductivity [4-7]. However, the low fracture toughness of HA ceramic limit the scope of clinical applications $[8,9]$. 
In recent years, more attention has been concentrated on developing novel bioactive based inorganic materials containing $\mathrm{CaO}-\mathrm{SiO}_{2}$ component for biomedical applications such as bioactive glasses [10-12], $\mathrm{CaSiO}_{3}$ ceramics [13] and AlW glass-ceramics [14, 15]. $\mathrm{CaO}-\mathrm{SiO}_{2}$ containing ceramics with different mechanical properties have shown excellent bioactivity when they are immersed in a SBF (simulated body fluid) or implanted into the bone defect [16, 17]. Previous studies have shown that bioglass and glass-ceramic containing $\mathrm{CaO}$ and $\mathrm{SiO}_{2}$ are possessing bioactivity $[18,19]$ and extensive investigations have confirmed that wollastonite $\left(\mathrm{CaSiO}_{3}\right)$ ceramics are bioactive and could directly bond to the bone in-vivo [20-22]. Nevertheless, the degradation of wollastonite is too fast and the mechanical strength is low [23]. Nakajima et al. has developed $\mathrm{Mg}$ containing $\mathrm{CaO}-\mathrm{SiO}_{2}$-based diopside $\left(\mathrm{CaMgSi}_{2} \mathrm{O}_{6}\right)$ ceramics to be used as biomaterials and has found that the diopside has the ability to form hydroxyapatite in SBF and could close bond to the bone tissue when implanted in rabbits [24, 25]. Furthermore, in-vitro and in-vivo studies by Nonami and Miake et al., they have confirmed that the diopside possesses good bioactivity with encountered mechanical properties compared with hydroxyapatite and wollastonite ceramics [26, 27]. However, its degradation was extremely low.

The high quality response of bioactive material is the formation of typical cauliflower-like HA, which is similar to bone apatite. It is obvious that most of the efforts were focused on the study of the behavior of single phase and the formation of HA irrespective to its morphology. In addition, the investigation of bioactivity of ceramic composites is still very modest and the bones and teeth of the human need tremendous efforts to find the best alternative materials.

This study aims at the processing and the investigation of different composite mixtures containing calcia-magnesia with additions of alumina, silica and zircon. These system powders were formed and sintered at two different temperatures. Phase composition and physical properties of these composites were determined. The in-vitro bioactivity of these sintered composites was assessed by analyzing the apatite layers produced on them using SBF as incubation medium. The apatite formation was analyzed using SEM-EDS (scanning electron microscope/energy dispersive X-ray spectrometry). The mechanical properties in terms of the bending strength of the composites that formed typically apatite "cauliflower" was determined.

\section{Materials and Experimental Procedure}

\subsection{Materials}

High pure powders of $\mathrm{CaCO}_{3}$ (supplied by El-Gomhouria Company, Egypt), magnesia(99\%) with mean particle size of $\sim 5 \mu \mathrm{m}$ (supplied by LOBA Chemie Pvt. Ltd, Mumbai, India), silica fume (99.8\%) (Aldrich chemical company, Inc, Milwaukee, WI, USA), Alumina ( $>99 \%$ ) with mean particle size of $2.5 \mu \mathrm{m}$ (supplied by Arabic Scientific office, Egypt) and zircon $(99.5 \%)$ with mean particle size of $1.16 \mu \mathrm{m}$ (El-Nasr Company for Refractories and Ceramics, Sornaga, Egypt) were used as starting materials. Ethanol was used for mixing.

\subsection{Experimental Procedure}

\subsubsection{Specimens Preparation}

Three batches containing calcia-magnesia with different additives from alumina, silica and zircon were prepared. Compositions of the investigated batches are given in Table 1. The powder mixtures and liquid ethanol were mixed in a planetary mill for $45 \mathrm{~min}$ using zirconia balls to ensure the homogeneity. The milled powders were dried and formed in a cylindrical shape at $60 \mathrm{MPa}$ using uni-axial press (KPD-30A, Spain). The specimens were dried for $24 \mathrm{~h}$ at $110{ }^{\circ} \mathrm{C}$, and then sintered at two different temperatures for $2 \mathrm{~h}$ in a programmable electric furnace. The temperature of the specimens was kept constant at a rate of $4{ }^{\circ} \mathrm{C}$ from room temperature up to the maximum firing temperature. 
Table 1 Composition of the investigated batches.

\begin{tabular}{llll}
\hline $\mathrm{Batch}$ & $\mathrm{I}$ & $\mathrm{II}$ & III \\
\hline $\mathrm{CaCO}_{3}$ & 29.07 & 38.46 & 48.01 \\
$\mathrm{MgO}$ & 11.6 & 15.39 & 9.58 \\
$\mathrm{Al}_{2} \mathrm{O}_{3}$ & 59.33 & - & - \\
$\mathrm{SiO}_{2}$ & - & 46.15 & - \\
$\mathrm{ZrSiO}_{4}$ & - & - & 42.41 \\
\hline $\mathrm{Calculated}$ chemical composition (wt.\%) & & & \\
\hline $\mathrm{CaO}$ & 18.67 & 25.92 & 34.08 \\
$\mathrm{MgO}$ & 13.3 & 18.52 & 12.16 \\
$\mathrm{Al}_{2} \mathrm{O}_{3}$ & 68.03 & - & - \\
$\mathrm{SiO}_{2}$ & - & 55.56 & 17.61 \\
$\mathrm{ZrO}$ & - & - & 36.15 \\
$\mathrm{C} / \mathrm{S} \mathrm{ratio}$ & $\mathrm{C} / \mathrm{A}=0.49$ & 0.49 & 2.07 \\
\hline $\mathrm{C}=\mathrm{Calcia}(\mathrm{CaO}), \mathrm{M}$ & $\mathrm{M}$ & \\
\hline
\end{tabular}

$\mathrm{C}=$ Calcia $(\mathrm{CaO}), \mathrm{M}=$ Magnesia $(\mathrm{MgO}), \mathrm{S}=$ Silica $\left(\mathrm{SiO}_{2}\right), \mathrm{Z}=$ Zirconia $\left(\mathrm{ZrO}_{2}\right)$ and $\mathrm{A}=$ Alumina $\left(\mathrm{Al}_{2} \mathrm{O}_{3}\right)$.

Table 2 Ion concentrations of c-SBF and human blood plasma (mM).

\begin{tabular}{lllllllll}
\hline & $\mathrm{Na}^{+}$ & $\mathrm{K}^{+}$ & $\mathrm{Mg}^{2+}$ & $\mathrm{Ca}^{2+}$ & $\mathrm{Cl}^{-}$ & $\mathrm{HCO}_{3}{ }^{-}$ & $\mathrm{HPO}_{4}{ }^{2-}$ & $\mathrm{SO}_{4}{ }^{2-}$ \\
\hline c-SBF & 142 & 5 & 1.5 & 2.5 & 147.8 & 4.2 & 1.0 & 0.5 \\
Blood plasma & 142 & 5 & 1.5 & 2.5 & 103 & 27 & 1.0 & 0.5 \\
\hline
\end{tabular}

The sintering temperatures of each batch were proposed based on the phase diagram [28-30] and after testing experimentally. One of these temperatures is the temperature after which the ceramic object melts. The other temperature was taken less than the maximum to examine its reflection on the object porosity and bioactivity as well.

\subsubsection{Characterizations}

\section{(1) Phase Composition and Microstructure}

Phase composition and crystalline phases in the fired specimens were identified by advanced $\mathrm{x}$-ray powder diffraction using a Brukur advanced X-ray diffractometer model D8 Kristalloflex (Ni-filtered $\mathrm{Cu}$ $\mathrm{K}_{\alpha}$ radiation; $\lambda=1.544 \AA$ ). The $\mathrm{XRD}$ was attached to semi-quantitative measurements to follow up the reaction sequence and phase content in the specimen.

Microstructural characterization of the specimens after heat treatments were performed using BSE (backscattered electron) in the field emission scanning electron microscopy (FESEM; QUANTA FEG 250, Holland). These investigations include the morphologies, textures, and distribution of the crystallized phases. The compositions of the phases were analyzed by EDS (energy dispersive X-ray spectroscopy) at areas on the sample surfaces. From these investigations, it is possible to determine the effects of heat treatment on the microstructural evolution, crystallization, pore, pore sizes and phase development.

(2) Evaluation of Bioactivity via Simulated Body Fluid

To evaluate the bioactivity of the different composites, c-SBF test (conventional simulated body fluid) was carried out. c-SBF is a cellular solution with an ion concentration similar to those of human blood plasma as given in Table 2. c-SBF solution was prepared as described by Oyane et al. [31] and buffered at $\mathrm{pH} \quad 7.4$ at $37{ }^{\circ} \mathrm{C}$ with tri-(hydroxymethyl) aminomethane and hydrochloric acid. The samples were mounted vertically in sterile polyethylene tubes for 7 days at $37{ }^{\circ} \mathrm{C}$. The amounts of SBF were calculated according to the formula of Kokubo T. and Takadama H. [32]. After soaking the samples, they were removed from SBF, rinsed with distilled water and dried at ambient conditions. After coating with a thin gold layer, the formation of hydroxyapatite was 
examined using a scanning electron microscope (SEM, Model CAM SCAN, Cambridge, U.K.) with EDS.

(3) Physico-Mechanical Tests

Apparent porosity and bulk density of fired specimens were determined by Archimedes immersion technique using kerosene [33].

Mechanical strength in terms of three-point bending test has been performed using a Zwick/Roell instrument with a span of $12 \mathrm{~mm}$ and at a constant crosshead speed of $0.2 \mathrm{~mm} / \mathrm{min}$. The tests were performed at room temperature. The sample size were $40 \mathrm{~mm} \times 5 \mathrm{~mm} \times 4.7 \mathrm{~mm}$. The time of all sample failures was 8-10 s. The three-point bending strength (S) was calculated with the following Eq. (1):

$$
S=3 P L / 2 b d^{2}
$$

where, $P$ is the maximum force, $L$ is the span length, $b$ is the sample width, and $d$ is the sample thickness. An average value was obtained from 15 samples tested for each case.

Fracture toughness KIC was determined by Vickers indentation. The procedure was described in our previous work [34].

\section{Results and Discussion}

\subsection{Phase Composition and Microstructure}

\subsubsection{Phase Composition}

Fig. 1 shows the XRD pattern of the formed batch "I" sintered at temperature of $1,400{ }^{\circ} \mathrm{C}$ and $1,500{ }^{\circ} \mathrm{C}$. These patterns display three phases termed magnesium aluminate spinel $\left(\mathrm{MgO} \cdot \mathrm{Al}_{2} \mathrm{O}_{3}\right.$, "MA" JCPDS \#77-1193), calcium mono-aluminate $\left(\mathrm{CaO} \cdot \mathrm{Al}_{2} \mathrm{O}_{3}\right.$, "CA" JCPDS \#70-0134) and calcium di-aluminate $\left(\mathrm{CaO} \cdot 2 \mathrm{Al}_{2} \mathrm{O}_{3}, \quad\right.$ "CA $\mathrm{CA}_{2}, \quad$ JCPDS\#72-0767). Semi-quantitative analysis of these patterns indicated that the content of " $\mathrm{CA}_{2}$ " decreased with the increase of the "MA" and "CA" content by increasing the temperature from $1,400{ }^{\circ} \mathrm{C}$ to $1,500{ }^{\circ} \mathrm{C}$. However, the relative intensities of the entire patterns decreased at $1,500{ }^{\circ} \mathrm{C}$. The change in the patterns might be back to the entrance of the batch on the next stage of the sintering process. At this stage, the phases start to gradually melt and liquefy followed by the damage of the crystal ordering forms amorphous structure. The $\mathrm{CaO}-\mathrm{MgO}-\mathrm{Al}_{2} \mathrm{O}_{3}$ system composition fired at $1,400{ }^{\circ} \mathrm{C}$

$$
\begin{aligned}
& \mathrm{C}=\text { Calcium Aluminum Oxide }\left(\mathrm{CaAl}_{2} \mathrm{O}_{4}\right) \\
& \mathrm{M}=\text { Magnesium Aluminum Oxide }\left(\mathrm{MgAl}_{2} \mathrm{O}_{4}\right) \\
& \mathrm{G}=\text { Grossite }\left(\mathrm{CaAl}_{4} \mathrm{O}_{7} / \mathrm{CaO} .2 \mathrm{Al}_{2} \mathrm{O}_{3}\right)
\end{aligned}
$$

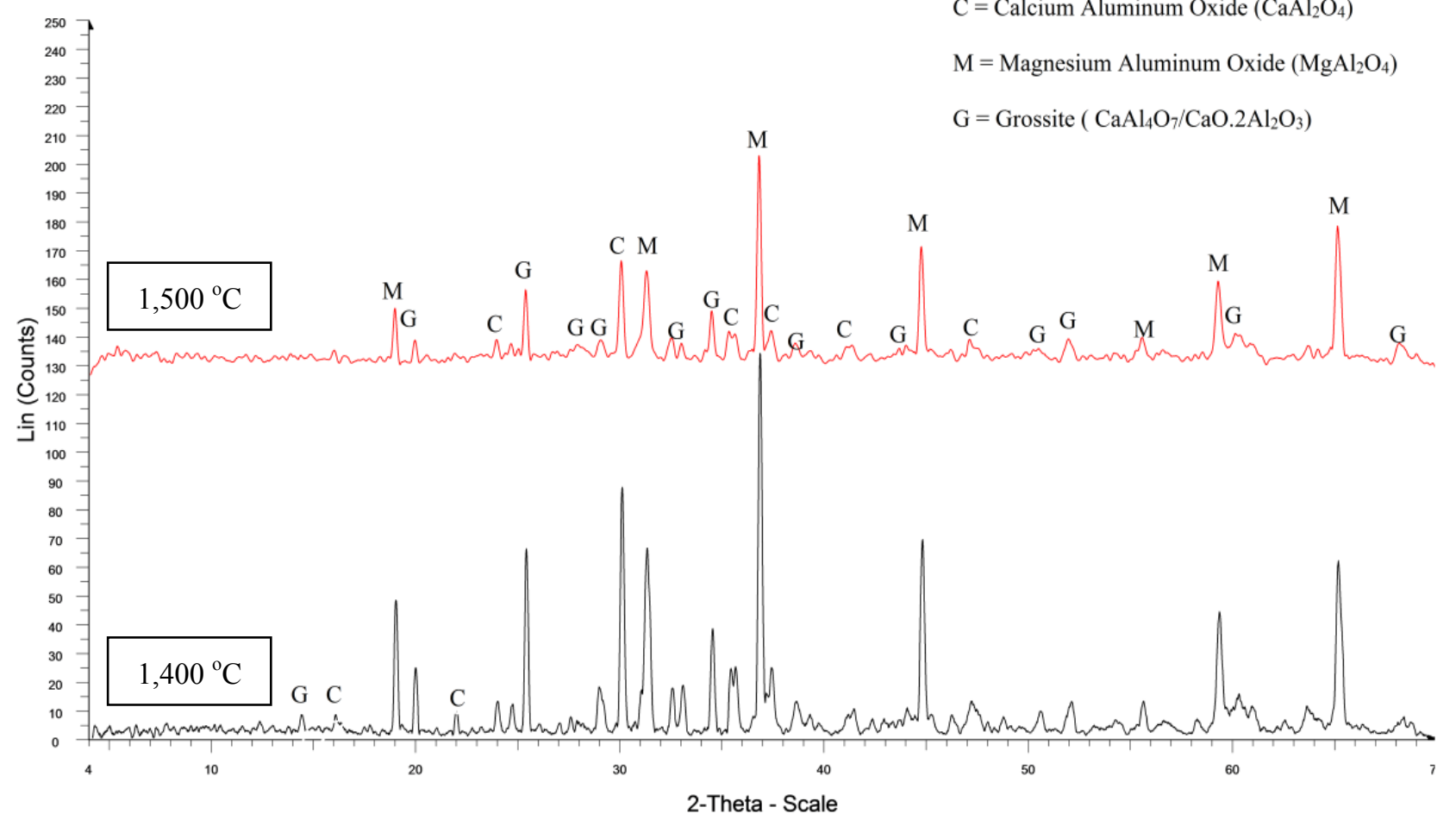

Fig. 1 XRD of batch "I" fired at $1,400{ }^{\circ} \mathrm{C}$ and $1,500{ }^{\circ} \mathrm{C}$. 
enable the formation of $\mathrm{CaO} \cdot \mathrm{Al}_{2} \mathrm{O}_{3}-\mathrm{MgO} \cdot \mathrm{Al}_{2} \mathrm{O}_{3}$ mixtures as a final product. These compositions are enveloped by triangle, the apices of which are points that corresponds to the $\mathrm{CA}, \mathrm{CA}_{2}$ and MA compositions (CA-CA $2-\mathrm{MA}$ ternary diagram). The optimal composition in this diagram that gives resulting minerals are containing $14 \%-21 \%$ of $\mathrm{CaO}, 5 \%-18 \%$ of $\mathrm{MgO}$ and $61 \%-81 \%$ of $\mathrm{Al}_{2} \mathrm{O}_{3}$ [28]. By the projection of the studied composition mixtures on this diagram, it will be located in the range of the optimal composition; however, there is a little increase of the $\mathrm{MgO}$ content. This increase in the concentration of $\mathrm{MgO}$ leads to growing of the fraction of MA spinel. By comparing the resulting mineral phases of the reported data and studied composition fired at $1,400{ }^{\circ} \mathrm{C}$, there is full agreement between both. Along with the presence of crystalline phases ( $\mathrm{CA}, \mathrm{CA}_{2}$ and $\left.\mathrm{MA}\right)$, some glassy phase is formed as well. With the increase of the firing temperature up to $1,500{ }^{\circ} \mathrm{C}$, this glassy phase increases, leading to a remarkable decrease in the entire patterns of XRD.

Fig. 2 shows the XRD pattern of the batch "II" fired at $1,200{ }^{\circ} \mathrm{C}$ and $1,300{ }^{\circ} \mathrm{C}$. At both temperatures, the batch is composed mainly of diopside

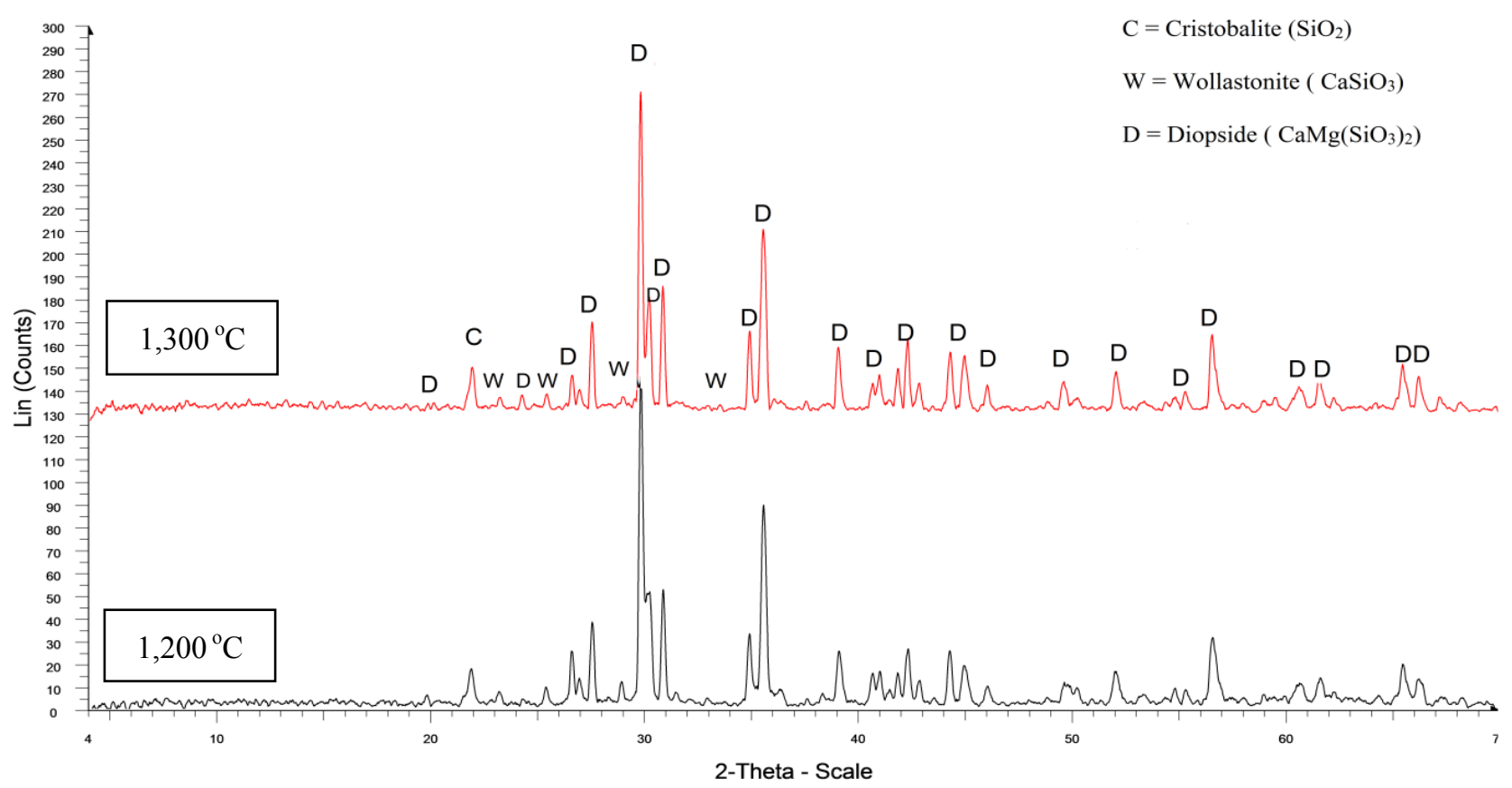

Fig. 2 XRD of batch “II" fired at $1,200{ }^{\circ} \mathrm{C}$ and $1,300{ }^{\circ} \mathrm{C}$.
$\left(\mathrm{CaO} \cdot \mathrm{MgO} \cdot 2 \mathrm{SiO}_{2}, " \mathrm{CMS}_{2}\right.$ ", JCPDS \#78-1390) and wollastonite phases with small amounts of cristobalite $\left(\mathrm{SiO}_{2}\right.$, "S", JCPDS \#76-0935). Nevertheless, with the increase of the firing temperature up to $1,300{ }^{\circ} \mathrm{C}$, the content of wollastonite was relatively increased in expense of diopside content. By the projection of the studied composition on $\mathrm{CaO}-\mathrm{MgO}-\mathrm{SiO}_{2}$ diagram prepared at $1,200{ }^{\circ} \mathrm{C}$ and $1,300{ }^{\circ} \mathrm{C}$ [29, 30], calcia, magnesia and silica were consumed in the formation of diopside mineral with small amount of wollastonite mineral and these outputs are agreed with our results.

Fig. 3 shows the XRD pattern of the batch "III" fired at $1,300{ }^{\circ} \mathrm{C}$ and $1,400{ }^{\circ} \mathrm{C}$. When the firing temperature is $1,300^{\circ} \mathrm{C}$, batch "III" is composed mainly of zirconia $\left(\mathrm{ZrO}_{2}\right.$, “Z”, JCPDS \#49-1642), merwinite (3CaO.MgO.2SiO $2, " \mathrm{C}_{3} \mathrm{MS}_{2}$ ", JCPDS \#35-0591) and monticellite (CaO· $\mathrm{MgO} \cdot \mathrm{SiO}_{2}$, "CMS", JCPDS \#76-75-1569) phases with little amount of calcium zirconium oxide $\left(\mathrm{CaO} . \mathrm{ZrO}_{2}\right.$, “CZ”, JCPDS \#76-2401) and periclase (MgO, "M", JCPDS\#27-1064). When the firing temperature increase up to $1,400{ }^{\circ} \mathrm{C}, \mathrm{C}_{3} \mathrm{MS}_{2}$ increased in expense of CMS content. In this composition, $\mathrm{CaO} / \mathrm{SiO}_{2}>1$, therefore, most of the magnesia added and liberated silica from the decomposition of 


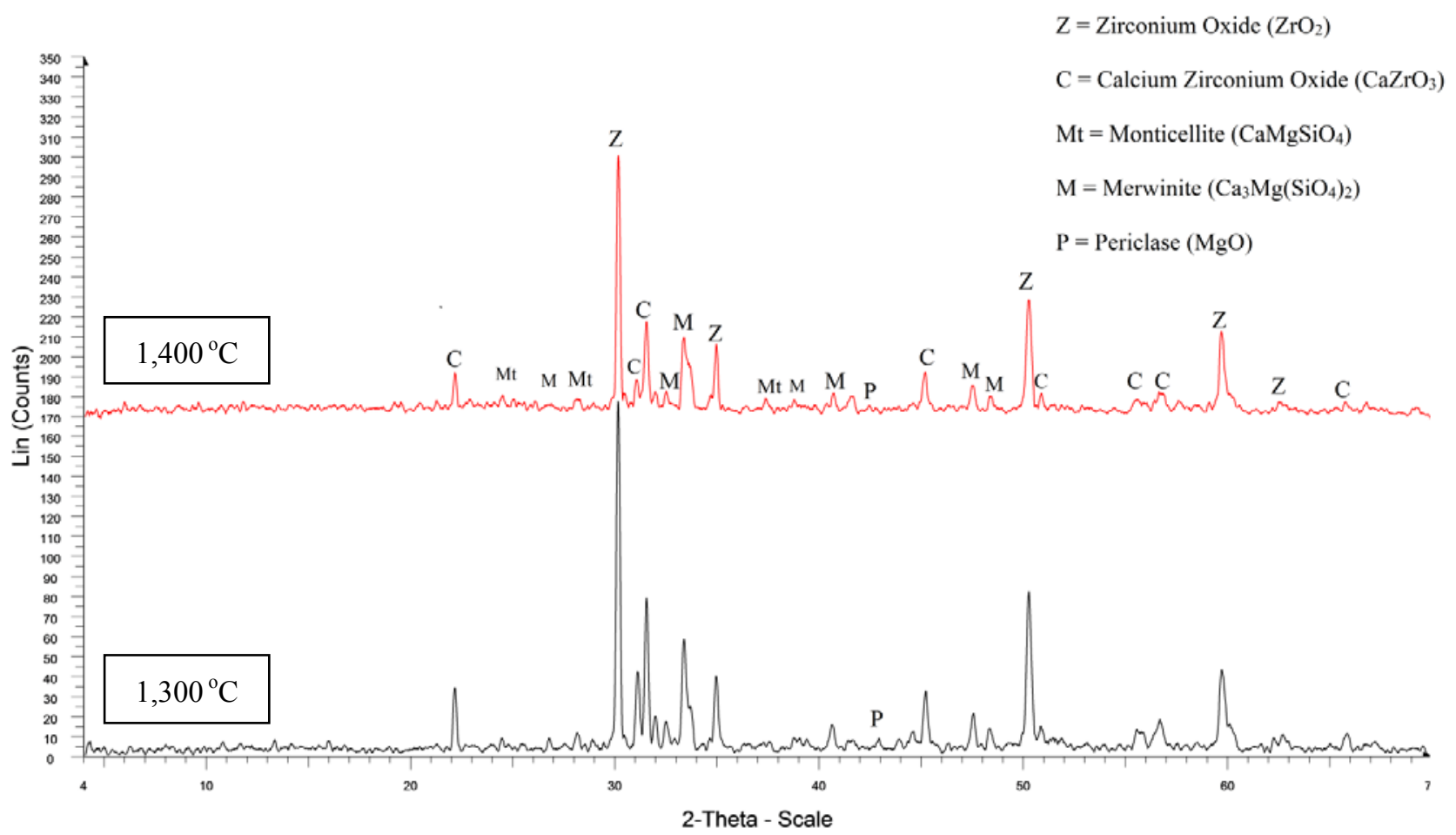

Fig. 3 XRD of batch "III" fired at $1,300{ }^{\circ} \mathrm{C}$ and $1,400{ }^{\circ} \mathrm{C}$.

zircon were consumed in the formation of merwinite and monticellite minerals. The remaining part of calcia reacted with part of liberated zirconia forming calcium zirconium oxide. The other part of zirconia in the presence of magnesia was crystallized in the form of cubic-zirconia, where $\mathrm{C}-\mathrm{ZrO}_{2}$ cannot be obtained unless it is doped by magnesia.

\section{Microstructure}

SEM micrographs of batch composition "I" fired at $1,400{ }^{\circ} \mathrm{C}$ and $1,500{ }^{\circ} \mathrm{C}$ are shown in Fig. 4. CA \& MA phases embedded in the $\mathrm{CA}_{2}$ matrix were seen. However, CA and MA phases were crystallized and become faceted when increasing the temperature from $1,400{ }^{\circ} \mathrm{C}$ to $1,500{ }^{\circ} \mathrm{C}$. The crystallite size of CA and $\mathrm{CA}_{2}$, calculated from XRD using Scherrer equation, decreased from 106.7 to $79.8 \mathrm{~nm}$ and 126.9 to $100 \mathrm{~nm}$, respectively, while the crystallite size of MA was increased slightly from $98.4 \mathrm{~nm}$ at $1,400{ }^{\circ} \mathrm{C}$ to $99.4 \mathrm{~nm}$ at $1,500{ }^{\circ} \mathrm{C}$. Therefore, MA does not show any remarkable change in its crystallite size. This means that the grain sizes of $\mathrm{CA}$ and $\mathrm{CA}_{2}$ phases were only influenced by the increase of firing temperature. Also, uniform distributed micropores were seen at low temperature as results from the evolution of the decomposition of $\mathrm{CaCO}_{3}$ and these pores were removed with exception of isolated micropores of diagonal value range from $3-11 \mu \mathrm{m}$ and aspect ratio range from 1 to 2.2 .

SEM micrographs of batch composition "II" fired at $1,200{ }^{\circ} \mathrm{C}$ and $1,300{ }^{\circ} \mathrm{C}$ are shown in Fig. 5. At lower temperature $\left(1,200{ }^{\circ} \mathrm{C}\right)$, the micrographs showed dendritic distributed diopside phase as thick struts for microspores, these pores are rounded to veins/networks-like feature. The size of diopside crystals was increased with the increase of temperature, and this growth was reflected by XRD investigation, where the crystallite size was changed from $87 \mathrm{~nm}$ to $105 \mathrm{~nm}$. The pore sizes and their aspect ratio are in the range of $0.1-8 \mu \mathrm{m}$ and $0.17-0.7$, respectively. On the other hand, the micropores were shrunk and become narrow and some of them were vanished and converted into isolated rounded pores with size values in the range of 2-7 $\mu \mathrm{m}$ and aspect ratio of 0.25 as a result of the effects of sintering at $1,300{ }^{\circ} \mathrm{C}$. It is worth noting that the increase of the sintering temperature of this batch 


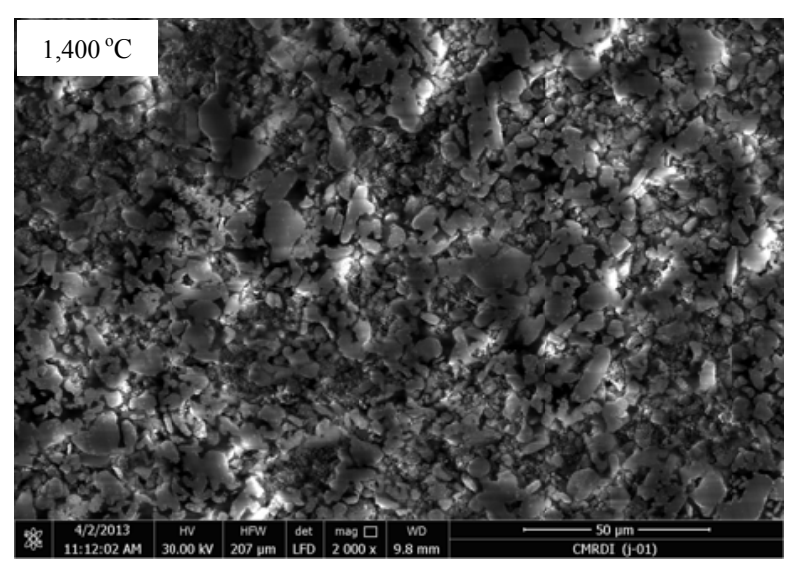

(a)

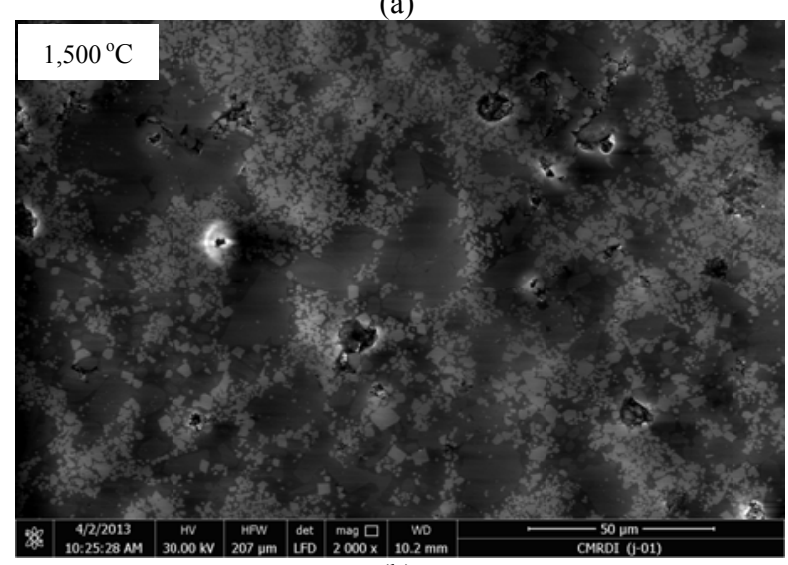

(b)

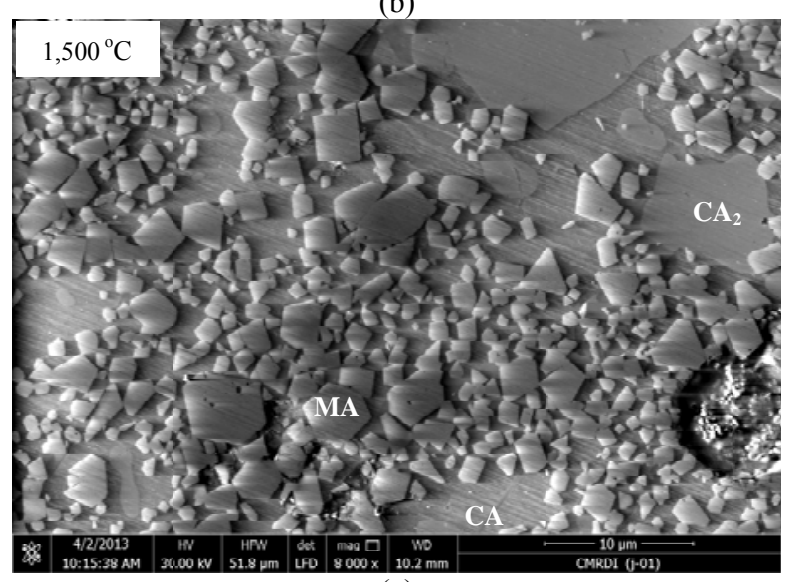

(c)

Fig. 4 FE-SEM micrographs of batch "I", $\mathrm{CA}_{2}$ : $\mathrm{CaO} \cdot 2 \mathrm{Al}_{2} \mathrm{O}_{3}$ and $\mathrm{MA}: \mathrm{MgO} \cdot \mathrm{Al}_{2} \mathrm{O}_{3}$.

contributed to the reduction of the porosity, their pore sizes and their morphologies but didn't remove it or vanish it. This means that larger pore sizes found, and the nature of diopside and wollastonite rods retard the shrinkage and consequently inhibit the densification of the batch. In addition, the decomposition of calcium carbonate in the presence of silica is also an important

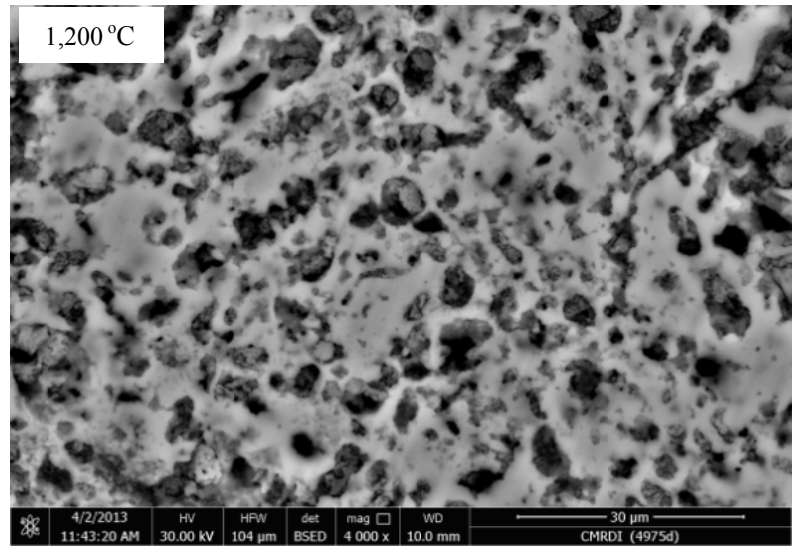

(a)

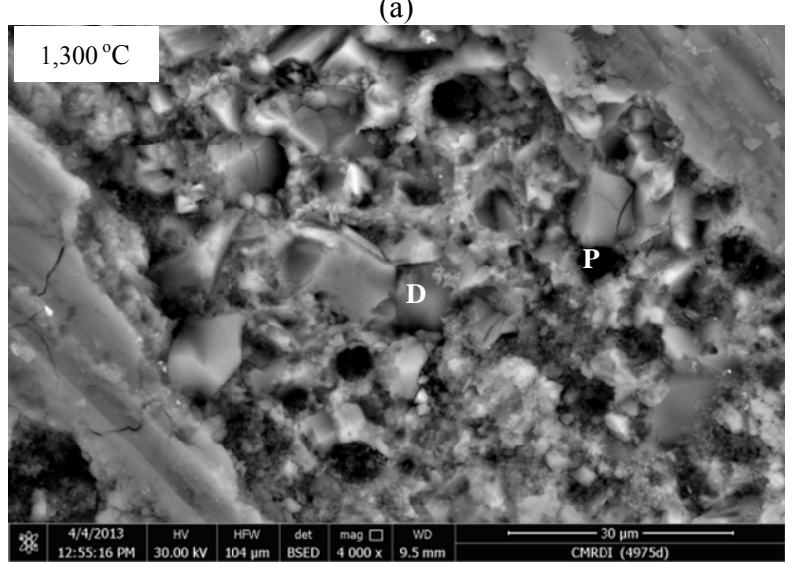

(b)

Fig. 5 FE-SEM micro graphs of batch "II", D: $\mathrm{CaO} \cdot \mathrm{MgO} \cdot 2 \mathrm{SiO}_{2}$, P: Pore.

factor in the creation of large pores and the retardation of their shrinkage. The question: can these pores vanish when increasing the temperature above $1,300{ }^{\circ} \mathrm{C}$ ? The answer: No, because the batch will completely melt. However, if the densification is one of the important factors in this batch, SPS (spark plasma sintering), HP (hot-pressing) or HIP (hot isostatic pressing) techniques can be used instead of pressureless sintering technique. We believe in our case, the produced object with this porosity is acceptable and could be targeted for the bioceramics material purposes.

SEM micrographs of batch composition "III" fired at $1,300{ }^{\circ} \mathrm{C}$ and $1,400{ }^{\circ} \mathrm{C}$ are shown in Fig. 6. Uniform distribution of $\mathrm{C}_{3} \mathrm{MS}_{2}$ (zirconia in merwinite)-CMS (monticellite) and $\mathrm{CZ}$ (calcium zirconate) mixtures at low temperature were seen while only one large magnesia grain was displayed. Likewise, the image revealed the presence of pores of interconnected 


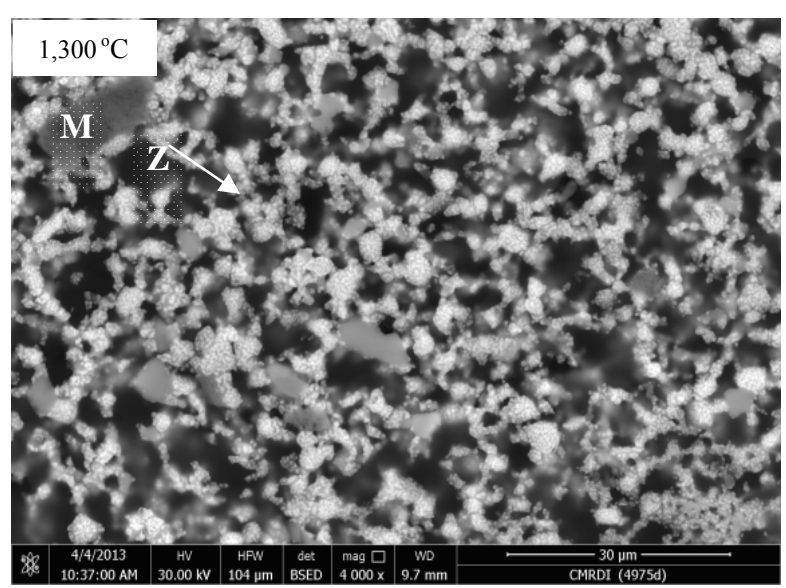

(a)
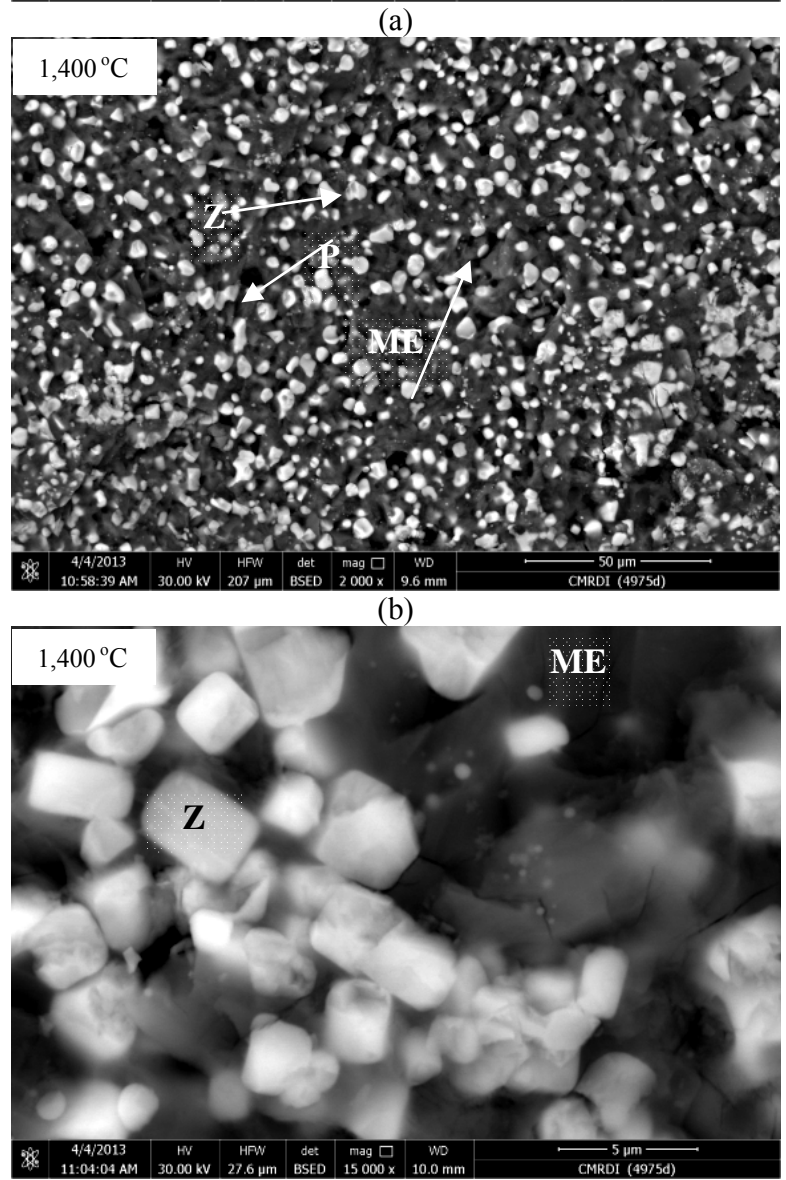

(c)

Fig. 6 FE-SEM micro graphs of batch “III", $\mathrm{Z}$ : $\mathrm{ZrO}_{2}, \mathrm{M}$ : $\mathrm{MgO}, \mathrm{ME}: 3 \mathrm{CaO} \cdot \mathrm{MgO} \cdot 2 \mathrm{SiO}_{2}$, and P: Pore.

vein-like. By increasing the temperature of sintering, highly distributed faceted zirconia grains of $\sim 5 \mu \mathrm{m}$ has been exhibited where the cubic faces and sharp edges started to appear. At the same time, magnesia was completely disappeared. As calculated from XRD using Scherrer equation, crystallite size of zirconia (99.5 nm at $1,300{ }^{\circ} \mathrm{C}$ and $97 \mathrm{~nm}$ at $1,400{ }^{\circ} \mathrm{C}$ ) did not show remarkable changes in size, while the crystallite sizes of merwinite and calcium zirconate were decreased from 43.7 and $90.4 \mathrm{~nm}$ at $1,300{ }^{\circ} \mathrm{C}$ to 33 and $57 \mathrm{~nm}$ at $1,400{ }^{\circ} \mathrm{C}$, respectively. It appears that the dissociated zirconia didn't leave their location while silica moved into the matrix and reacted with the other components like magnesia and calcia. In addition, very few isolated rounded pores of $\sim 4.9 \mu \mathrm{m}$ were seen. The tailored microstructures at both temperatures are of course natural reflection for accompanied reaction as a result of thermal treatment, where the only source of pore phase is the evolved $\mathrm{CO}_{2}$ from calcium carbonate dissociation. On the other hand, in this composition, the presence of the high specific weight of zircon and non free silica in the matrix contributed to densification and in turn removing the pores.

\section{In-vitro Bioactivity of the Batches}

Figs. 7-12 show the SEM photographs of the surfaces of the fired batches before and after soaking in SBF for 7 days. As seen in Fig. 7, the nucleation of apatite was started and the whole surface of the batch "I" fired at $1,400{ }^{\circ} \mathrm{C}$ for $2 \mathrm{~h}$ was covered by inorganic phosphate within the 7 days of immersion as proved by EDS analysis. By increasing the temperature of firing up to $1,500{ }^{\circ} \mathrm{C}$, cubic and spindel-shaped HA crystallite was formed and the whole surface was nearly covered by hydroxyapatite (Fig. 8). These phases were approved by EDS analysis as seen in Fig. 8 . Based on this test result, the produced samples at both firing temperatures seems to have the potential to be bioactive because of the formation of the HA. As it is well-known, the described mechanisms for the formation of the apatite structure from calcium silicate phases takes place from the formation of gel structure [35-37]. In the investigated system and in the frame of the experimental condition, $\mathrm{CA}$ (calcium monoaluminate) and $\mathrm{CA}_{2}$ (calcium dialumiante) phases have a strong tendency to be hydrated, and formed $\mathrm{CAH}_{10}$ and $\mathrm{AH}_{3}$ gels, respectively [38]. Hence, the mechanisms of the formation of the apatite might be similar to bioactive silicate system. The presence of 


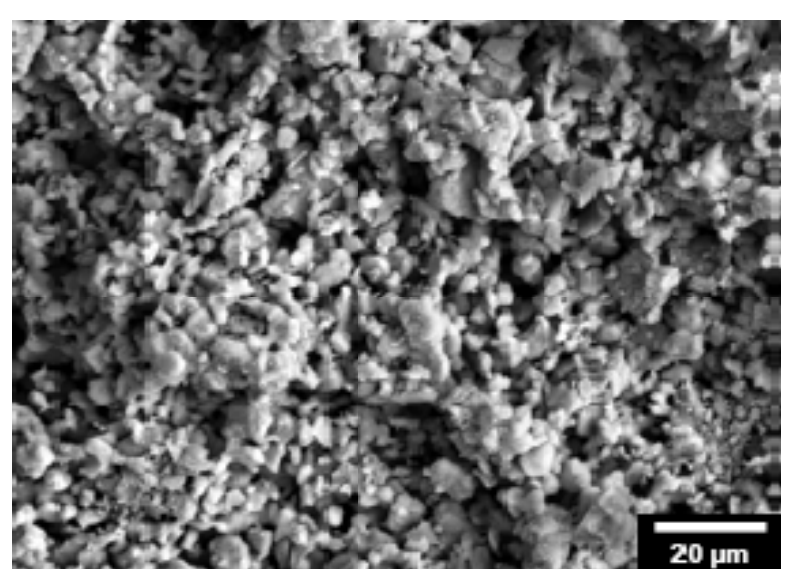

(a) Before immersion in SBF

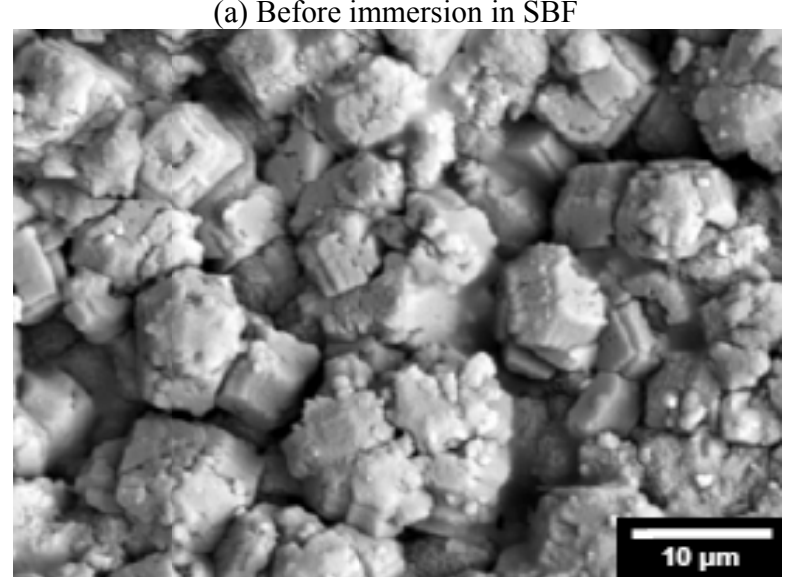

(b) After immersion in SBF

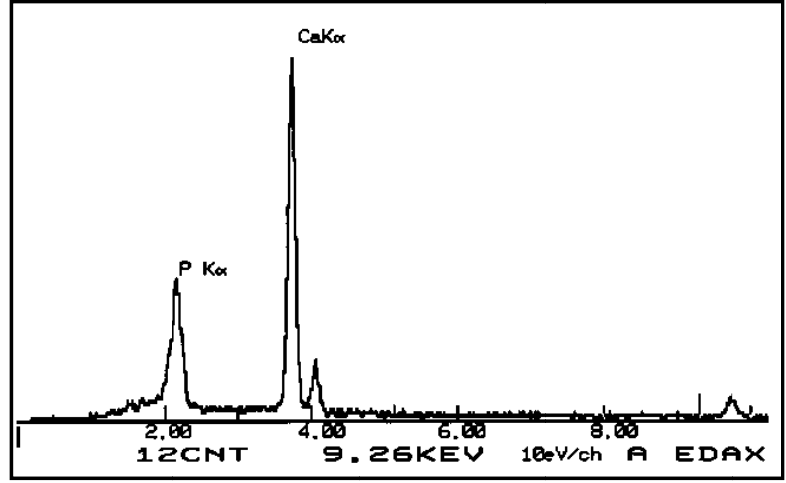

(c)

Fig. 7 SEM micrographs of batch "I" fired at $1,400{ }^{\circ} \mathrm{C}$ before and after immersion in SBF.

calcium aluminate phases, as reported in literature, form apatite on their surfaces as exposed to phosphate buffer solution [36, 37]. Since MA spinel phase is bioinert, the biological activities displayed by this composition are attributed to calcium aluminate phases. Thus, this composite can work as osteoceramics and can be nominated as a biomaterial in orthopaedic and dental applications [38-40].
By merging the calcia and magnesia with silica in the termed composition "II", the whole surface was nearly covered by hydroxyapatite and this is confirmed by EDS analysis (Figs. 9 and 10). However, the nucleation was started in the fired sample at a temperature of $1,200{ }^{\circ} \mathrm{C}$. On the other hand, the HA formed on the surface of the sample fired at $1,300{ }^{\circ} \mathrm{C}$ took the typical "cauliflower" morphology. These attractive results might come from the presence of two bioactive composite phases (diopside and wollastonite) of this batch. It seems that the increase of the diopside at the expense of wollostonite in presence of reasonable porosity could help in the formation of cauliflower structure. The mechanism of the formation of bone-like apatite in this system might be back to the dissolution of wollastonite and partial dissolution of diopside in SBF [41]. Whereas, the former release $\mathrm{Ca}^{2+}$ (aq.), $\mathrm{HSiO}_{3}^{-}$(aq.) and $\mathrm{OH}^{-}$(aq.) and the latter release $\mathrm{Ca}^{2+}$ (aq.), $\mathrm{HSiO}_{3}{ }^{-}$(aq.), $\mathrm{Mg}^{2+}$ (aq.) and $\mathrm{OH}^{-}$(aq.). The concentration of the released ions at the neighborhood of the reacting surface increases with time of immersion until it exceeds the solubility product of the HA. During the process of $\mathrm{Ca}^{2+}$ release from solid solution, many silanol groups $(\mathrm{Si}-\mathrm{OH})$ are formed on the surface of $\mathrm{CS}_{-} \mathrm{CMS}_{2}$ composite which induces heterogeneous nucleation of apatite. Once the released calcium ions increase, the ionic activity product of apatite increases as well and enhances apatite nucleation. Moreover, the composites produced at both temperatures have large porosities and this porosity could induce and enhance the nucleation of apatite. Recently, the work published has indicated that the bioactivity of composite composed of diopside-wallostonite decreases with the increase of wallostonite content. In contrast, the investigated composite forms bone-like apatite although it has a very small amount of wallostonite $(\sim 6 \%-10 \%)$ compared with the published composite containing $\sim 37 \%$ CS [41].

With the addition of zircon and further addition of calcia to magnesia to tailor batch III, the produced 

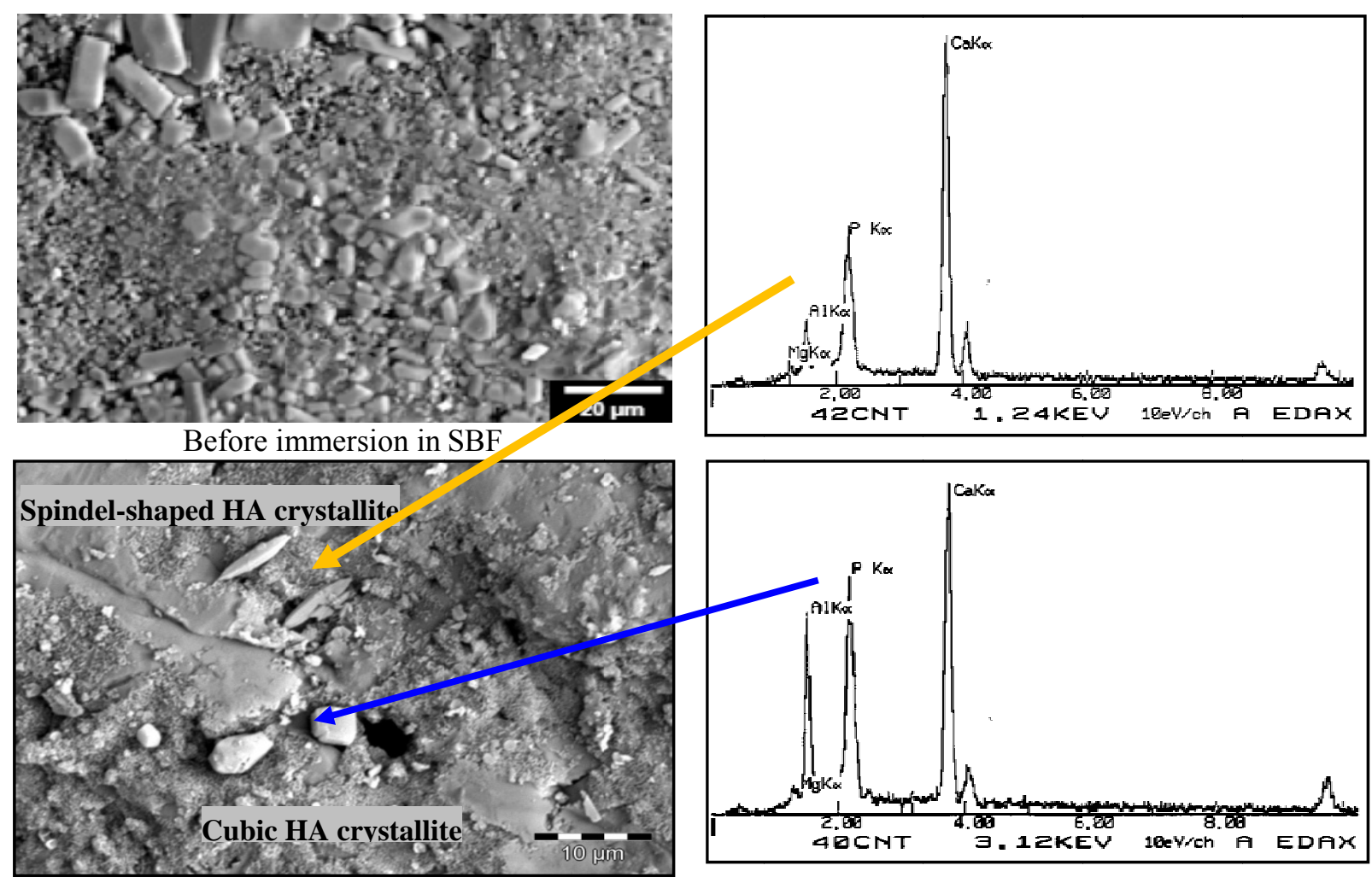

After immersion in SBF

Fig. 8 SEM micrographs of batch "I" fired at $1,500{ }^{\circ} \mathrm{C}$ before and after immersion in SBF.

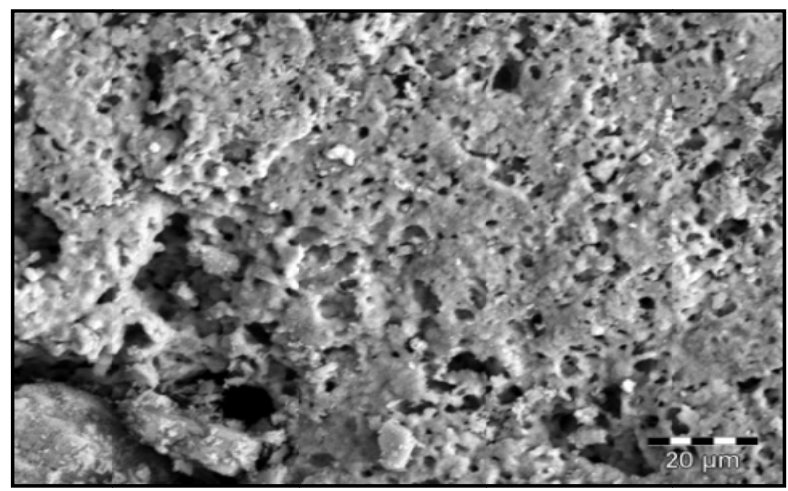

Before immersion in SBF

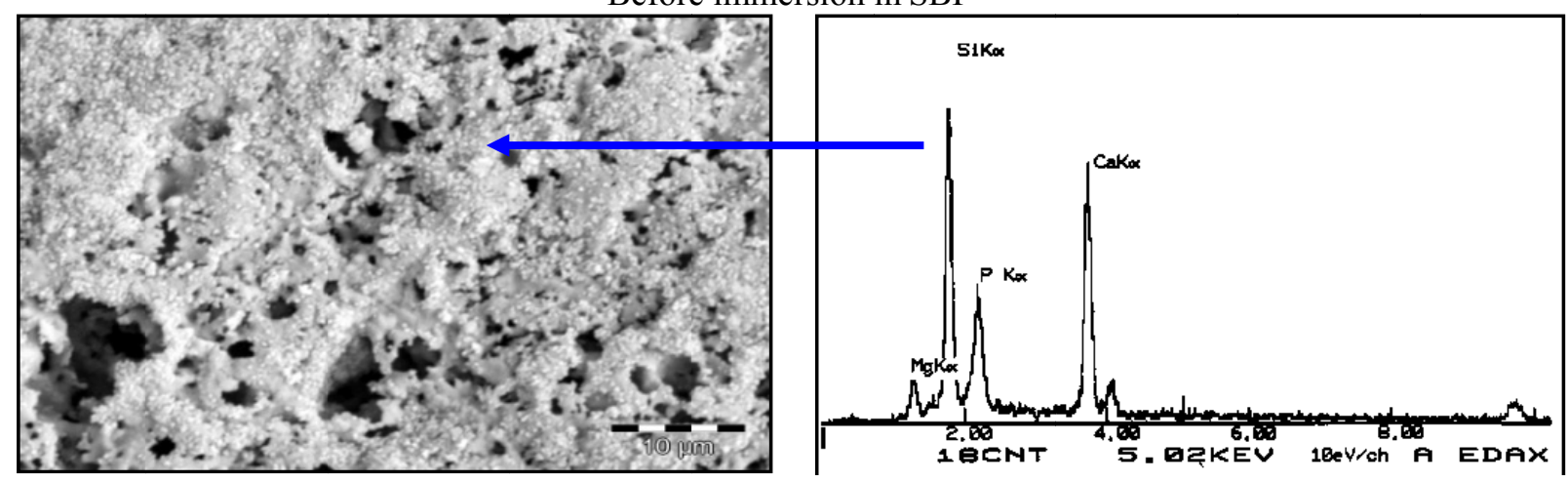

After immersion in SBF

Fig. 9 SEM micrographs of batch "II" fired at $1,200^{\circ} \mathrm{C}$ before and after immersion in SBF. 


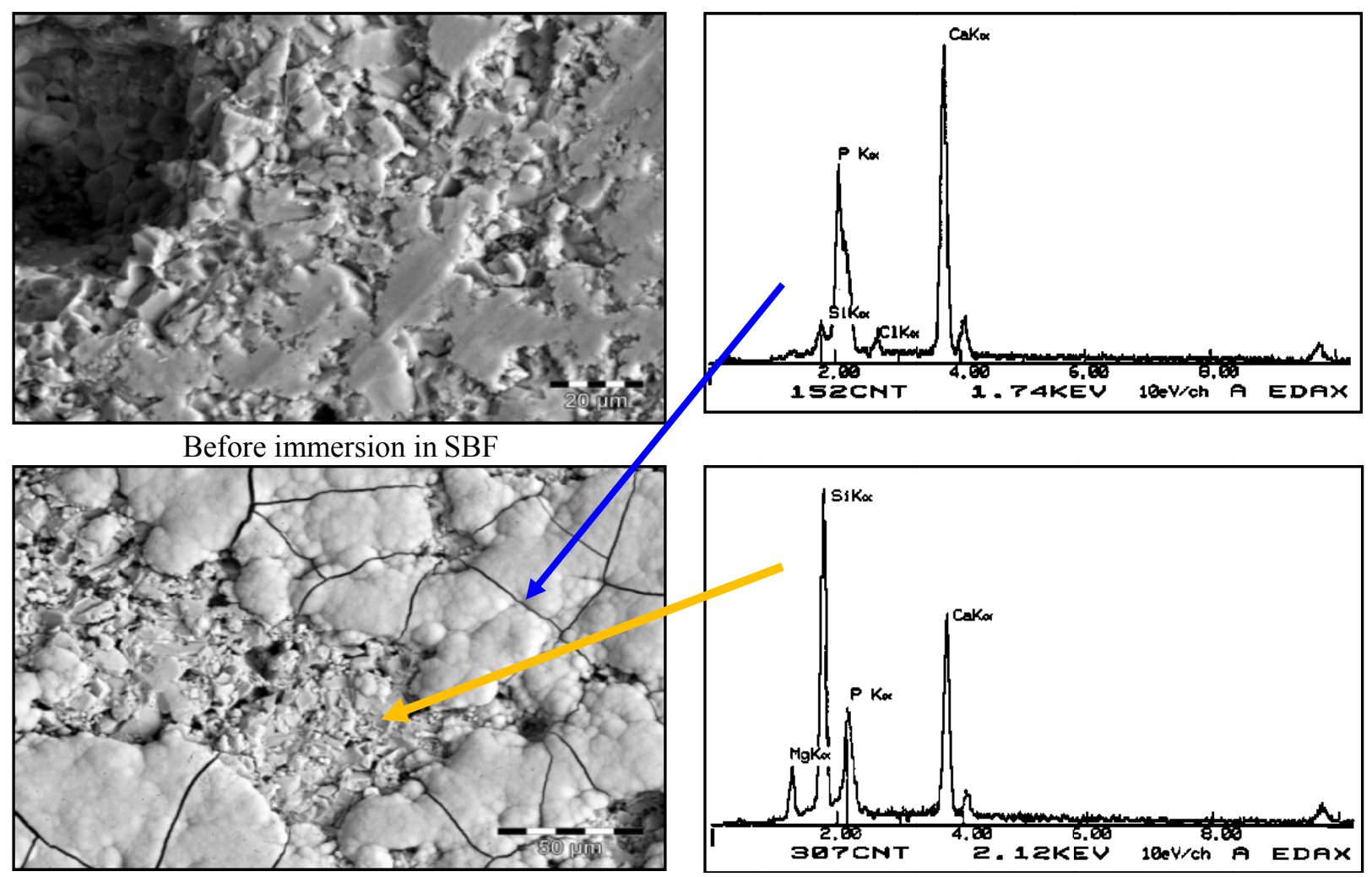

After immersion in SBF

Fig. 10 SEM micrographs of batch "II" fired at $1,300{ }^{\circ} \mathrm{C}$ before and after immersion in SBF.

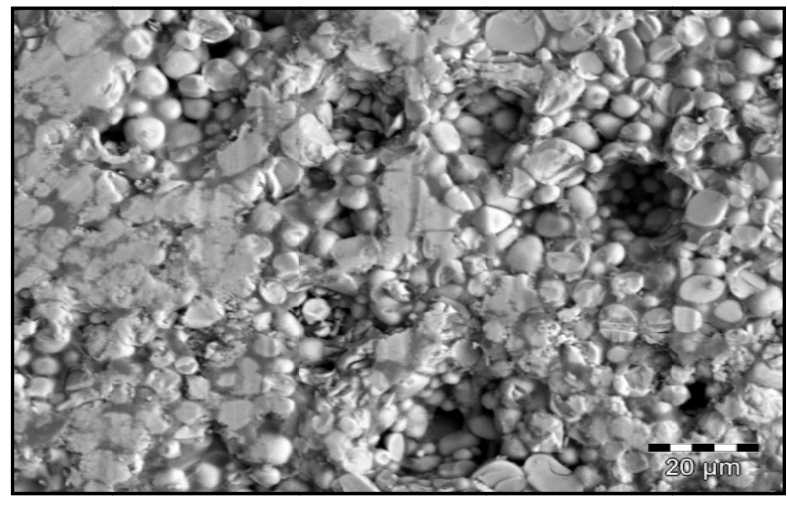

Before immersion in SBF

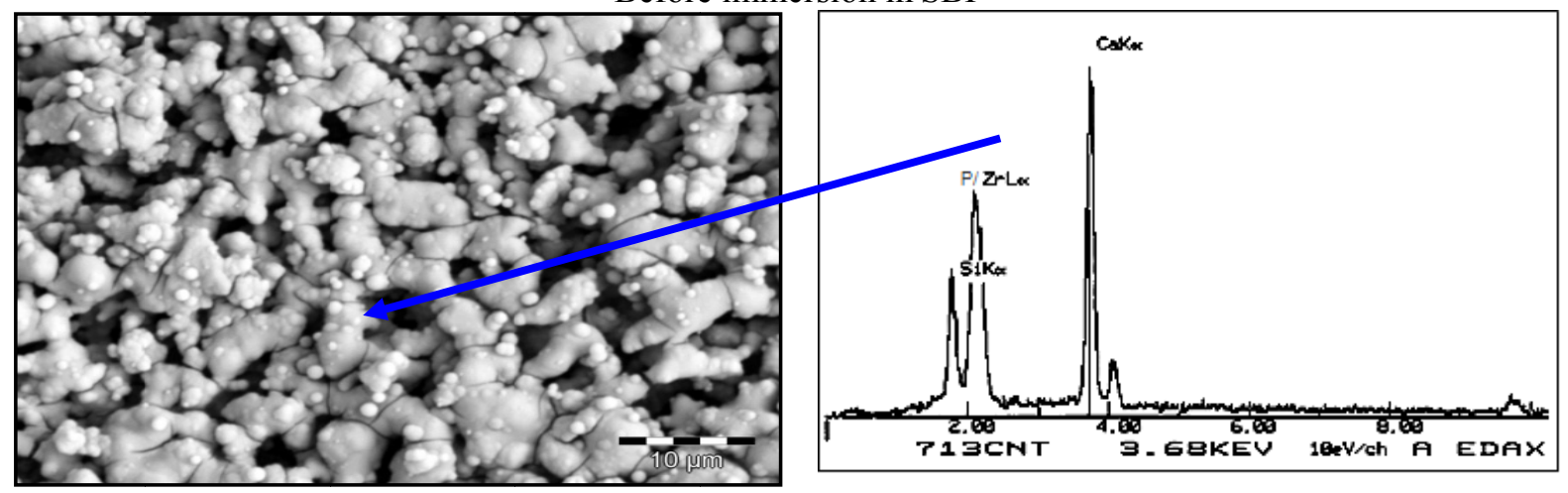

After immersion in SBF

Fig. 11 SEM micrographs of batch "III" fired at $1,300{ }^{\circ} \mathrm{C}$ before and after testing in SBF. 


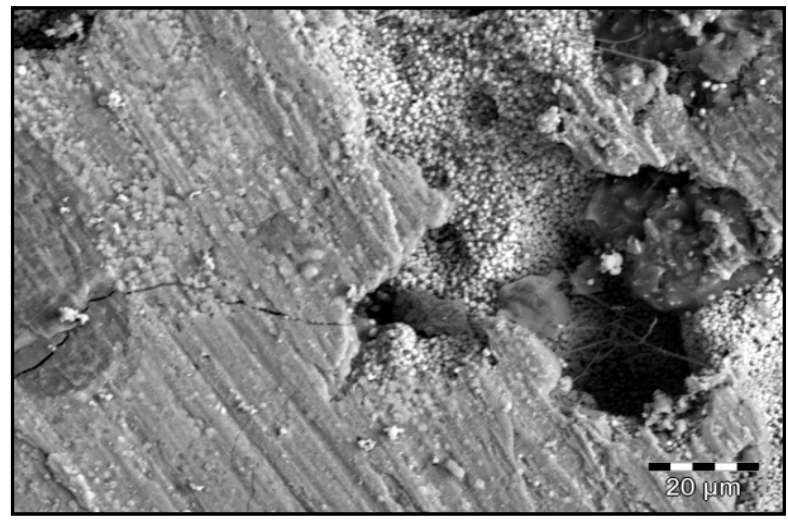

Before immersion in SBF

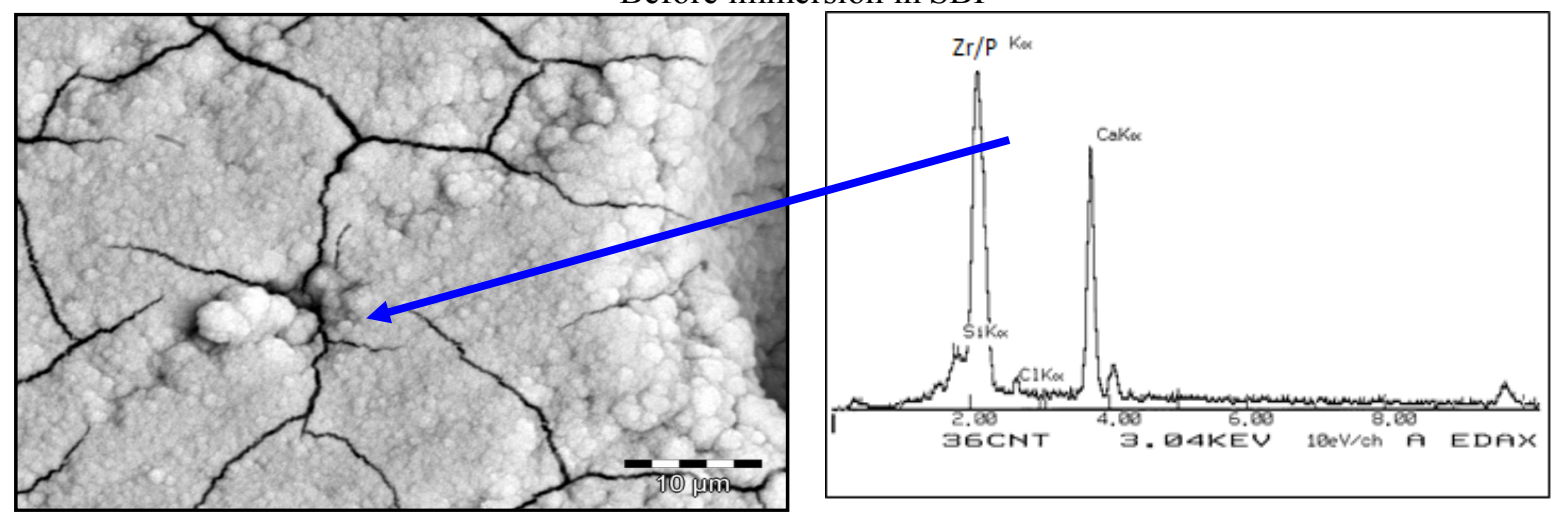

After immersion in SBF

Fig. 12 SEM micrographs of batch "III" fired at $1,400{ }^{\circ} \mathrm{C}$ before and after testing in SBF.

samples fired at $1,300{ }^{\circ} \mathrm{C}$ and $1,400{ }^{\circ} \mathrm{C}$ have the similar behaviour with the previous samples of the batch II. Whereas, the nucleation of apatite started in the fired samples at a temperature of $1,300{ }^{\circ} \mathrm{C}$ and the whole surface of both samples were covered by inorganic phosphate (Figs. 11 and 12). The interesting thing here is the formation of HA crystal in the form of "cauliflower". The produced composite contains two bioactive phases like merwinite-monticellite. These phases are expected to be responsible for the formation of HA. As reported recently, some single composition in $\mathrm{CaO}-\mathrm{MgO}-\mathrm{SiO}_{2}$ system like akermanite $\left(\mathrm{Ca}_{2} \mathrm{MgSi}_{2} \mathrm{O}_{7}\right)$, bredigite $\left(\mathrm{Ca}_{7} \mathrm{MgSi}_{4} \mathrm{O}_{16}\right)$, merwinite [42] and monticellite [43, 44] ceramic phases [42-47] do not only possess an improved mechanical strength when compared with hydroxyapatite and wollastonite ceramics, but also were degradable and revealed bone-like apatite formation ability in SBF. In addition, the ionic products from akermanite and bredigite could stimulate cell proliferation [46, 47]. Based on our results, the composite phases in this system gave different forms of HA crystals including the best form of HA (Cauliflower). These composites could simulate the cell proliferation comparing with single composition and control the morphology of HA. These results indicated that the studied compositions might be used as novel bioactive materials for bone regeneration.

This composition has various anticipated competitive mechanisms that can contribute to the formation of bonelike apatite. As it is well-known that zirconia degradation at low temperature is a progressive and spontaneous phenomenon which is exacerbated in the presence of water, steam or fluids. The solubility of zirconia depends mainly on $\mathrm{pH}[48,49]$. In the condition of our investigated system, the composite surface might be functionalized by $\mathrm{OH}$ as a result of chemisorption of $\mathrm{H}_{2} \mathrm{O}$ forming $\mathrm{Zr}-\mathrm{OH}$ groups. Also, another part of zirconia is anticipated to be dissolved to zirconium hydroxide. These groups from 
$\mathrm{Zr}-\mathrm{OH}$ are able to induce apatite nucleation in a similar manner to Si-OH, Ti-OH, and Ta-OH groups [50].

Recently, immersion of merwinite " $\mathrm{C}_{3} \mathrm{MS}_{2}$ " or monticellite "CMS" ceramics in SBF could release soluble ionic products, which in turn induce surface precipitation of Ca-P rich layers. These soluble ions significantly stimulate osteoblast proliferation, and osteoblasts adhered and spread well on merwinite ceramic surfaces $[49,50]$. This composite is very rich by the bioactive phases termed, $\mathrm{Z}, \mathrm{C}_{3} \mathrm{MS}_{2}$ and CMS.

\section{Physico-Mechanical Properties}

Densification parameters in term of bulk densities and apparent porosity properties of the fired batches I, II and III, were recorded in Table 3. When increasing the firing temperature of the batch "I" from $1,400{ }^{\circ} \mathrm{C}$ to $1,500{ }^{\circ} \mathrm{C}$, the bulk density increased from 2.79 to $2.94 \mathrm{~g} / \mathrm{cm}^{3}$, while the apparent porosity decreased from $55.46 \%$ to be $1.07 \%$. The pores of this batch seem to be closed and produced near-fully dense at $1500{ }^{\circ} \mathrm{C}$.

Nevertheless, increasing the firing temperature of batch II from $1,200{ }^{\circ} \mathrm{C}$ to $1,300{ }^{\circ} \mathrm{C}$, the bulk density increased from 1.31 to $2.77 \mathrm{~g} / \mathrm{cm}^{3}$, while the apparent porosity decreased from $56.24 \%$ to $31.4 \%$. In this reaction, the batch components were completely reacted when the firing temperature increases, but it seems that the densification was retarded and produced porous body. This indicates that reaction completion before densification could be better to remove the pores. In all situations, the pressureless sintering of this batch produces porous composite body.

However, increasing the firing temperature of batch III from $1,300{ }^{\circ} \mathrm{C}$ to $1,400{ }^{\circ} \mathrm{C}$, the bulk density increased from 1.52 to $3.3 \mathrm{~g} / \mathrm{cm}^{3}$, while the apparent porosity decreased from $59.74 \%$ to $2.59 \%$. It is obvious that apparent porosity values approach zero in batches I and III at $1,400{ }^{\circ} \mathrm{C}$ and $1,500{ }^{\circ} \mathrm{C}$, respectively. This denotes near-fully sintered composition.

The physico-mechanical properties of the composite II fired at $1,300{ }^{\circ} \mathrm{C}$ and the composite III fired at $1,400{ }^{\circ} \mathrm{C}$, which formed typically apatite "cauliflower"; are compared with HA and human cortical bone given in Table 4. In general, the mechanical strengths of the sintered ceramics are correlated with the densification [51, 52]. In our study, the apparent porosity obtained for batch II ceramics at a temperature after which the composition would be melted was $31.3 \%$, which suggests that a further improvement of the mechanical properties might be possible by the novel super-fast consolidation technique, spark plasma sintering [53], which might lead to a further increase of the densification of the batch II ceramics. However, the properties of this composition without other treatment can be nominated as porous bioactive ceramic material.

Table 3 Densification parameters of the composite mixtures at the respective firing temperatures.

\begin{tabular}{lllllll}
\hline Properties & \multicolumn{3}{c}{ I } & \multicolumn{3}{l}{ II } \\
\hline Firing temperature $\left({ }^{\circ} \mathrm{C}\right)$ & 1,400 & 1,500 & 1,200 & 1,300 & 1,300 & 1,400 \\
Apparent porosity $(\%)$ & 55.46 & 1.07 & 56.24 & 31.4 & 59.74 & 2.59 \\
Bulk density $\left(\mathrm{g} / \mathrm{cm}^{3}\right)$ & 2.79 & 2.94 & 1.31 & 2.77 & 1.52 & 3.3 \\
\hline
\end{tabular}

Table 4 Physico-mechanical properties of promised bioceramic materials compared with HA and human cortical bone.

\begin{tabular}{lllll}
\hline Properties & II & III & HA & Human cortical bone \\
\hline Firing temperature $\left({ }^{\circ} \mathrm{C}\right)$ & 1,300 & 1,400 & & \\
Apparent porosity $(\%)$ & 31.4 & 2.59 & - & - \\
Bulk density $\left(\mathrm{g} / \mathrm{cm}^{3}\right)$ & 2.77 & 3.3 & 3.16 & $1.6-2.1$ \\
Hardness $(\mathrm{GPa})$ & 2 & 6 & 6 & $1-2.3$ \\
Fracture toughness $\left(\mathrm{MPa} \cdot \mathrm{m}^{0.5}\right)$ & 4.6 & 2.1 & $0.75-1$ & $2-12$ \\
Bending strength $(\mathrm{MPa})$ & 95.1 & 102 & $80-89$ & $50-150$ \\
Apatite mineralization ability & Strong & Extra-strong & Good & - \\
\hline
\end{tabular}


As reported, the bending strength, fracture toughness and hardness of sintered HAP ceramics are 115-200 MPa, $0.75-1 \mathrm{MPa} \cdot \mathrm{m}^{1 / 2}$ and $6 \mathrm{GPa}$, respectively $[54,55]$. In this study, a comparable bending strength $(95,102 \mathrm{MPa})$ of II and III fired at $1,300{ }^{\circ} \mathrm{C}$ and $1,400{ }^{\circ} \mathrm{C}$ respectively were recorded. A significant improvement in the fracture toughness $\left(4.6,2.1 \mathrm{MPa} \cdot \mathrm{m}^{1 / 2}\right)$ of II and III, and a considerable decrease in the hardness for II (2 GPa) was seen but hardness was close to that of III (6 GPa).

Based on the reported data and the obtained results for the investigated compositions, both batches, II and III fired at $1,300{ }^{\circ} \mathrm{C}$ and $1,400{ }^{\circ} \mathrm{C}$, respectively, possess good bioactivity, biocompatibility and mechanical properties similar to those of human cortical bone and might be a promising bone for different applications like implantations, coating and scaffolds.

\section{Conclusions}

AP (Bone like apatite) play an essential role in the formation, growth and maintenance of the tissue-biomaterials interface, and this AP layer can be reproduced in vitro in SBF [56, 57]. In this study, our results indicated that batch "I" displayed two types of hydroxyl apatites. In the mean time, it contains bioinert MA spinel phase. Thus, this composite can be worked as osteoceramics and can be nominated as a biomaterial in orthopaedic and dental applications based on the reported data [38-40]. The other two batches, II and III were completely covered by apatite and have the ability to form the typical "cauliflower" morphology as seen in the previous images. Based on the reported data and the obtained results for the investigated compositions, both batches II and III fired at $1,300{ }^{\circ} \mathrm{C}$ and $1,400{ }^{\circ} \mathrm{C}$, respectively, possessed good bioactivity, biocompatibility and mechanical properties similar to those of human cortical bone and might be a promising bone for different applications like implantations, coating and scaffolds.

\section{References}

[1] Williams, D. F. 1987. Definitions of Biomaterials.
Amsterdam: Elsevier.

[2] Shackelford, J. F. 1999. "Bioceramics: Current Status and Future Trends." Mater. Sci. Forum. 293: 99-106.

[3] Dubok, V. A. 2000. "Bioceramics: Yesterday, Today, Tomorrow." Powder Metal Metal Ceram. 39 (7-8): 381-394.

[4] Ogushi, H., Goldberg, V. M., and Caplan, A. I. 1989. "Hetrotopic Osteogenesis in Porous Ceramics Induced by Marrow Cells.” J. orthop. Res. 7: 568-78.

[5] Stephenson, P. K., Freeman, M. N., Revell, P. A., Germain, J., Tuke, M., and Pirie C. J. 1991. "The Effect of Hydroxyapatite Coating on Ingrowth of Bone Into Cavities of an Implant." J. Arthroplasty 6: 51-58.

[6] Guan, J. L, and Chen, H. C. 1996. "Signal Transduction in Cell-Matrix Interactions.” Int. Rev. Cytol. 168: 82-121.

[7] Shores, E. C., and Holmes R. E. 1993. "Porous Hydroxyapatite." In an Introduction to Bioceramics, edited by Hench L. L., and Wilson J. Singapore: World scientific, 181-198.

[8] Legeros, R. Z., and Legeros, J. P., 1993. "Dense Hydroxyapatite." In an Introduction to Bioceramics, edited by Hench L. L., and Wilson J. Singapore: World scientific, 139-180.

[9] Suchanek, W., and Yoshimura, M. 1998. "Processing and Properties of Hydroxyapatite-Based Biomaterials for Use as Hard Tissue Replacement Implants." J. Mater. Res. 13: 94-117.

[10] Izquierdo-Barba, I., Salinas, A. J., and Valet-Regi, M. 1999. "In Vitro Calcium Phosphate Formation on Sol-Gel Glasses of The $\mathrm{CaO}-\mathrm{SiO}_{2}$ System." J. Biomed. Ater. Res. 47: 243-250.

[11] Izquierdo-Barba, I., Salinas, A. J., and Valet-Regi, M. 2000. "Effect of The Continous Solution Exchange on The In Vitro Reactivity of a $\mathrm{CaO}-\mathrm{SiO}_{2}$ Sol-Gel Glass." $J$. Biomed. Ater. Res. 51: 191-9.

[12] Salinas, A. J., Valet-Regi, M., and Izquierdo-Barba, I. 2001. "Biomimetic Apatite Deposition on Calcium Silicate Gel Glasses.” J. Sol-gel Sci. Technol. 21: 13-25.

[13] Siriphannon, P., Kameshima, Y., Yasumori, A., Okada, K., and Hayashi, S. 2000. "Influence of Preparation Conditions on The Microstructure and Bioactivity of A-CasiO ${ }_{3}$ Ceramics: Formation of Hydroxapatite in Simulated Body Fluid.” J. Biomed. Mater. Res. 52: 30-9.

[14] Kokubo, T., Ito, S., Huang, Z. T., Hayashi, T., Sakka, S., Kitsugi, T.,and et al. 1990. "Ca, P-rich Layer Formed on High-strength Bioactive Glass Ceramic A-W.” J. Biomed. Mater. Res. 24: 331-343.

[15] Yoshii, S., Kakutani, Y., Yamamuro, T., Nakamura, T., Kitsugi, T., Oka, M., Kokubo, T., and Takagi, M. 1988. "Strength of Bonding Between A-W Glass Ceramic and the Surface of Bone Cortex." J. biomed. Mater. Res. 22(A): 327-338. 
[16] Oonishi, H., , Hench, L. L., Wilson, J., Sugihara, F., Tsuji, E., Matsurra, M., and et al. 2000. "Guantitative Comparison of Bone Growth Behavior in Granules of Bioglass, A-W Glass-ceramic, and Hydroxyapatite." J. biomed. Mater. Res. 51: 37-46.

[17] Kokubo, T. 1990. "Surface Chemistry of Bioactive Glass-ceramics." J. noncryst. Solid.120: 138-151.

[18] Merrollli, A., Tranquilli, L. P., and Guidi, P. L. 2000. "Comparison in In-vivo Response Between A Bioactive Glass and Non-bioactive Glass.” J. Mater. Sci. Mater. Med. 11: 219-222.

[19] Hench, L. L. 1991. "Bioceramics: From Concept to Clinic." J. Am. Ceram. Soc. 74: 1487-1510.

[20] Siriphannon, P., Hayashi, S., Yasumori, A., and Okada, K. 1999. "Preparation and Sintering of $\mathrm{CaSiO}_{3}$ From Coprecipitated Powder Using $\mathrm{NaOH}$ as Precipitant and Its Apatite Formation in Simulated Body Fluid Solution." J. Mater. Res. 14: 529-536.

[21] Ni, S. Y., Chang, J., Chou, L., and Zhai, W. Y. 2007. "Comparison of Osteoblast-like Cell Response to Calcium and Tricalcium Phosphate Ceramics in Vitro." J. Biomed. Mater. Res. B Appl. Biomater. 80: 174-183.

[22] Xue, W. C., Liu, X. Y., Zheng, X. B., and Ding, C. X. 2005. "In Vivo Evaluation of Plasma-sprayed Wollastonite Coating." Biomaterials 26: 3455-3460.

[23] Lin, K. L., Zhai, W. Y., Chang, J., Zeng, Y., and Qian, W. J. 2005. "Study of Mechanical Property and in Vitro Biocompatibility of CaSiO3 Ceramics." Ceram. Inter. 31: 323-6.

[24] Nakajima, S., Kurihara, Y., Wakatsuki, Y., and Noma, H. 1989. "Physicochemical Characteristics of New Reinforcement Ceramic Implant.” Shikwa. Gakuho. 89: 1709-1717.

[25] Nakajima, S. 1990. "Experimental Studies of Healing Process on Reinforcement Ceramic Implantation in Rabbit Mandible." Shikawa. Gakuho. 4: 525-553.

[26] Miake, Y., Yanagisawa, T., Yajima, Y., Noma, H., Yasui, N., and Nonami, T. 1995. "High-resolution and Analytical Electron Microscopic Studies Crystals Induced by A Bioactive Ceramic (diopside)." J. Dent. Res. 74: 1756-1763.

[27] Nonami, T., and Tsutsumi, S. 1999. "Study of Diopside Ceramics for Biomaterials." J. Mater. Sci. Mater. Med. 10: 475-9.

[28] Sarkisov, P. D., Sivkov, S. P., Kuznetsova, T. V., and Meshalkin, V. P. 2013. "Using the Methods of Thermodynamic Analysis to Optimize the Composition of High Refractory Cements in the $\mathrm{CaO}-\mathrm{Al}_{2} \mathrm{O}_{3}-\mathrm{MgO}$ System." Theoretical Foundations of Chemical Engineering 47 (1): 10-13.

[29] Data from FToxide-FACT Oxide Database. 2010. "Collection of Phase Diagrams: $\mathrm{CaO}-\mathrm{MgO}-\mathrm{SiO}_{2}-1200{ }^{\circ} \mathrm{C}$."
Accessed

2010.

http://www.crct.polymtl.ca/fact/phase_diagram.php?

[30] Data from FToxide-FACT oxide database 2010, "Collection of phase diagrams: $\mathrm{CaO}-\mathrm{MgO}-\mathrm{SiO}_{2}-1300{ }^{\circ} \mathrm{C}$," Accessed 2010. http://www.crct.polymtl.ca/fact/phase_diagram.php?

[31] Oyane, A., Kim, H. M., Furuya, T., Kokubo, T., Miyazaki, T., and Nakamura, T. 2003. "Preparation and Assessment of Revised Simulated Body Fluids." J. Biomed. Mater. Res. Part A. 65A: 188-195.

[32] Kokubo, T., and Takadama, H. 2006. "How Useful is SBF in Predicting in Vivo Bone Bioactivity?" Biomaterials 27: 2907-2915.

[33] ASTM C830-00 (2011) Standard Test Methods for Apparent Porosity, Liquid Absorption, Apparent Specific Gravity, and Bulk Density of Refractory Shapes by Vacuum Pressure.

[34] Ewais, E. M. M., Attia, M. A. A., Abousree-Hegazy, A., and Bordia, R. K. 2010. "Investigation of the Effect of $\mathrm{ZrO}_{2}$ and $\mathrm{ZrO}_{2} / \mathrm{Al}_{2} \mathrm{O}_{3}$ Additions on the Hot-pressing and Properties of Equimolecular Mixtures of $\alpha$ - and $\beta-\mathrm{Si}_{3} \mathrm{~N}_{4}$." Ceramics International 36 [4]: 1327-1338.

[35] Li, P., Ohtsuki, C., Kokubo, T., Nakanishi, K., Soga, N., Nakamura, T., and Yamamuro, T. 1992. "Apatite Formation Induced by Silica Gel in a Simulated Body Fluid." J. Am. Ceram. Soc. 5 [8]: 2094-7.

[36] Cho, S. B., Nakanishi, K., Kokubo, T., Soga, N., Ohtsuki, C., Nakamura, T., Kitsugi, T., and Yamamuro, T. 1995. "Dependence of Apatite Formation on Silica Gel on Its Structure: Effect of Heat Treatment." J. Am. Ceram. Soc. 78.[7]: 1769-1774.

[37] Liu, X., Ding, C., and Chu, PK. 2004. "Mechanism of Apatite Formation on Wollastonite Coatings in Simulated Body Fluids.” Biomaterials 25: 1755-1761.

[38] Nilforoushan, M. R., and Talebian, N. 2007. "The Hydration Products of a Refractory Calcium Aluminate Cement at Intermediate Temperatures." Iran. J. Chem. Chem. Eng. 26 [3]: 19-24.

[39] Hermansson, L. 2011. "Nanostructural Chemically Bonded Ca-Aluminate Based Bioceramics.” Biomaterials Physics And Chemistry. http://www.intechopen.com/books/biomaterials-physics-a nd-chemistry/nanostructural-chemically-bonded-caalumi nate-based-Apatite bioceramics.

[40] Hermansson, L., Loof, J., Glantz, P-O., and Abrahamsson, E. 2012. Calcium aluminate based paste for stabilizing dental implants and restoring tissue attachment after surgery and methods therefore. US patent 20120189983 , filed October 2, 2009, and issued July 26, 2012.

[41] Sainz, M. A., Pena, P., Serena, S., and Caballero, A. 2010. "Influence of Design on Bioactivity of Novel $\mathrm{CaSiO}_{3}-\mathrm{CaMg}\left(\mathrm{SiO}_{3}\right)_{2}$ Bioceramics: In Vitro Simulated 
Body Fluid Test and Thermodynamic Simulation.” Acta. Biomaterialia. 6: 2797-2807.

[42] Bhatkar, V. B., and Bhatkar, N. V. 2011. "Combustion Synthesis and Photoluminescence Characteristics of Akermanite: A Novel Biomaterial.” Int. J. Adv. Eng. Sci. and Tech. 5[2]: 184-186.

[43] Ou, J., Kang, Y., Huang, Z., Chen, X., Wu, J., Xiao, R., and Yin, G. 2008. "Preparation and in Vitro Bioactivity of Novel Merwinite Ceramic.” Biomed. Mater. 3: 8-10.

[44] Chen, X., Ou, J., Kang, Y., Huang, Z., Zhu, H., Yin, G., and Wen, H. 2008. "Synthesis and Characterization of Monticellite Bioactive Ceramic.” J. Mater. Sci. Mater. Med. 19(3): 1257-1263.

[45] Wu, C. T., Chang, J., Zhai, W. Y., Ni, S. Y., and Wang, J. Y. 2006. "Porous Akermanite Scaffolds for Bone Tissue Engineering: Preparation, Characterization, and in Vitro Studies." J. Biomed. Mater. Res. B Appl. Biomater. 78: 47-55.

[46] Wu, C., Chang, J., Ni, S., and Wang. J. 2006. "The in Vitro Bioactivity of Akermanite Ceramics." J. Biomed. Mater. Res. A 76: 73-80.

[47] Wu, C. T., Chang, J., Wang, J. Y., Ni, S. Y., and Zhai, W. Y. 2005. "Preparation and Characteristics of A Calcium Magnesium Silicate (Bredigite) Bioactive Ceramics." Biomaterials 26: 2925-2931.

[48] James, H. A., Krarup, H. G., Venigalla, S., and Tsukada, T. A. 1997. "Review of the Aqueous Chemistry of the Zirconium-Water System to $200{ }^{\circ} \mathrm{C}$." In Materials Research Society Symposium Proceedings (MRS
Proceedings), 432.

[49] Qiu, L., Guzonas, D. A., and Webb, D. G. 2008. "Solubility of Zirconium Dioxide at Elevated Temperatures," ICPWS XV, Berlin, September 8-11..

[50] Uchida, M., Kim, H. M., Kokubo, T., Miyaji, F., and Nakamura, T. 2001. "Bonelike Apatite Formation Induced on Zirconia Gel in a Simulated Body Fluid and Its Modified Solutions." J. Am. Ceram. Soc. 84 [9]: 2041-4.

[51] Shi, J. I. 1999. "Thermodynamics and Densification Kinetics in Solid-state Sintering of Ceramics." J. mater. Res. 14: 1398-1408.

[52] Rice, R. W. 1996. "Grain Size and Porosity Dependence of Ceramic Fracture Energy and Toughness at $22^{\circ} \mathrm{C} . " J$. Mater. Sci.31 (8): 1969-1983.

[53] Shen, Z., Adolfsson, E., Nygren, M., Gao, I., Kawaoka, H., and Niihara, K. 2001. "Dense Hydroxyapatite-zirconia Ceramic Composites with High Strength for Biological Applications." Adv. Mater. 13: 214-6.

[54] Hench, L. L. 1998. "Bioceramics.” J. Am. Ceram. 81 (7): 1705-1728.

[55] Ravaglioli, A., and Krajewski, A. 1992. Bioceramics-Materials, Properties and Applications. London: Chapman \&Hall.

[56] Kokubo, T. 1990. "Surface Chemistry of Bioactive Glass-ceramics.” J. Non-crest. Solids. 51: 120-138.

[57] Ishaug, S. L., Yaszemski, M. J., Bizious, R., and Mikos, A. G. 1994. "Osteoblast Function on Synthetic Biodegradable Polymers." J. biomed. Mater. Res. 28: 1445-1453. 